\title{
Response of Symphyotrichum novi-belgii and Dianthus chinensis L. to saline water irrigation in a coastal saline soil
}

\author{
Xiaobin Li ${ }^{a, b}$, Yaohu Kang ${ }^{a, *}$, Shuqin Wan ${ }^{a}$, Xiulong Chen ${ }^{a, b}$, Jiachong Xu ${ }^{a, b}$ \\ ${ }^{a}$ Key Laboratory of Water Cycle and Related Land Surface Processes, Institute of Geographic Sciences and Natural Resources Research, Chinese Academy of \\ Sciences, Beijing 100101, China \\ ${ }^{\mathrm{b}}$ University of Chinese Academy of Sciences, Beijing 100049, China
}

\section{A R T I C L E I N F O}

\section{Article history:}

Received 28 December 2015

Received in revised form 22 February 2016

Accepted 10 March 2016

Available online 19 March 2016

\section{Keywords:}

Symphyotrichum novi-belgii

Dianthus chinensis L.

Salt leaching

Survival

Shoot dry mass

\begin{abstract}
A B S T R A C T
Symphyotrichum novi-belgii and Dianthus chinensis L. perform well in landscape. However, their tolerance to salinity stress is unknown. Field experiment was conducted to evaluate the salt tolerance threshold (STI) of these two herbaceous plants cultivated in a coastal saline soil by drip-irrigation with saline water at electrical conductivity (EC) of $0.8,3.1,4.7,6.3$, and $7.8 \mathrm{dS} / \mathrm{m}$ for three years. The original soil salinity expressed as electrical conductivity of the saturation paste extract $\left(E C_{e}\right)$ was an average of $27.64 \mathrm{dS} / \mathrm{m}$ in the 0-95 cm depth. Our results showed that drip-irrigation was effective in salt leaching. After $18 \mathrm{months}$, the average values of soil $\mathrm{EC}_{\mathrm{e}}$ for five treatments were 2.32 and $2.78 \mathrm{dS} / \mathrm{m}$ in $0-35$ and $0-95 \mathrm{~cm}$ soil profile, respectively. The survival rates were $>94 \%$ and $>80 \%$ when irrigated with saline water at $<7.8 \mathrm{dS} / \mathrm{m}$ for S. novi-belgii and $D$. chinensis L., respectively. The survival rate and shoot dry mass decreased by $0.76 \%$ and $9.24 \%$ for each unit of EC increase in the irrigation water for S. novi-belgii, and the corresponding values were $3.01 \%$ and $8.21 \%$ for $D$. chinensis L. This study implied that S. novi-belgii and D. chinensis L. are suitable plants in landscape construction of coastal saline soils using drip-irrigation with suitable saline water range.
\end{abstract}

(c) 2016 Elsevier B.V. All rights reserved.

\section{Introduction}

With the development of industrialization and urbanization in coastal regions, there is an urgent need to improve the landscape to meet the increasing demand of living environments for cities and districts (Li et al., 2015a,b). However, around some cities and districts there are many saline soils and saline water, which is one of the major environmental and land degradation problems in the world, and is also a major constraint to the cultivation of crops and landscape plants in coastal regions. In recent years, a simple and rapid method for vegetation landscape reconstruction in saline coastal soils using drip-irrigation has been proposed and improved by the authors' group (Chen et al., 2015; Li et al., 2015a,b,c; Sun et al., 2012, 2013). The method has been successfully applied to the shrub plant (Chen et al., 2015; Li et al., 2015a,b,c; Sun et al., 2012, 2013). In order to extend the variety of plant types to construct a better and attractive landscape in coastal saline soils, and also

\footnotetext{
* Corresponding author at: Key Laboratory of Water Cycle and Related Land Surface Processes, Institute of Geographic Sciences and Natural Resources Research, Chinese Academy of Sciences, 11 A Datun Road, Anwai, Beijing 100101, China.

E-mail address: kangyh@igsnrr.ac.cn (Y. Kang).
}

extend the application of the proposed reclamation method and display its popularization, further studies are needed concerning salt tolerance of other landscape plants using drip-irrigation with saline water in coastal saline soils.

Symphyotrichum novi-belgii and Dianthus chinensis L. are perennial flower and important landscaping materials with good viewing. These two herbaceous plants do not need extensive management, and can endure cold, barren, drought and other harsh environments. As kinds of cover plant, S. novi-belgii and D. chinensis $\mathrm{L}$. have been widely applied in garden and road greening in the coastal ecology landscape construction for their beautiful flowers, longer flowering period and simple management in China. However, there is a dearth of information on these two plants subjected to salinity in field soil irrigated with saline water, and the suitable irrigation water salinity ranges were still unknown.

S. novi-belgii and $D$. chinensis $L$. were selected as test plants in this experiment, and were planted in coastal regions with very severely saline sandy loam soil, and received irrigation water at five levels of salinity using drip-irrigation. The aim of the study was to test the responses of $S$. novi-belgii and $D$. chinensis $\mathrm{L}$. to saline water irrigation when grown in coastal saline soils and make out the suitable irrigation water salinity ranges. 


\section{Materials and methods}

\subsection{Site description}

The field experiment was conducted during 2013-2015 on coastal saline land in Industrial Zone of Caofeidian District $\left(39^{\circ} 03^{\prime} \mathrm{N}\right.$, $118^{\circ} 48^{\prime} \mathrm{E}$ ) in the south of Tangshan city, east China, and north of Bohai Gulf which borders the Pacific Ocean. The station has a typical semi-humid monsoon climate with annual precipitation of approximately $580 \mathrm{~mm}$, mostly during June-September. The $\mathrm{EC}_{\mathrm{e}}$ and sodium adsorption rate (SAR) of the soil at a depth of $95 \mathrm{~cm}$ are $27.64 \mathrm{dS} / \mathrm{m}$ and $53.17(\mathrm{mmol} / \mathrm{L})^{0.5}$, respectively. According to the USDA soil classification, the soil in our experiment field was sandy loam soil, with clay $(<0.002 \mathrm{~mm})$ content of $0.51 \%$, silt $(0.002-0.05 \mathrm{~mm})$ of $42.23 \%$ and sand $(0.05-2 \mathrm{~mm})$ of $56.26 \%$. The field capacity, permanent wilting point and total amount of plant available water were about $24 \%, 7 \%$ and $17 \%$ (Volumetric Water Content) in $0-20 \mathrm{~cm}$ soil profile, respectively. The initial soil texture, soil bulk density, $\mathrm{EC}_{\mathrm{e}}, \mathrm{pH}$ and SAR are shown in Table 1.

\subsection{Plot layout and irrigation}

In this study, soils were treated as described in Li et al. (2015a,b,c). It mainly included soil removal, laying the gravel and sand layer, soil backfilling, land leveling and vegetation planting. Firstly, a certain depth of undisturbed soil in the saline-sodic land, which was selected for reconstructing the landscape, was excavated using a large backhoe (Fig. 1a). Secondly, a 15-cm thick layer of gravel (particle size of $3-5 \mathrm{~cm}$ ) was laid in the bottom of the excavation and then covered with a $5-\mathrm{cm}$ thick layer of sand (particle size $0.2-0.4 \mathrm{~cm}$ ), to reduce capillarity of the soil (Fig. $1 \mathrm{~b}$ and c). Thirdly, native saline-sodic soils were placed back above the gravel-sand layer (Fig. 1d). And a rotary tiller was used to break clay blocks and oyster shell of the soil surface to increase soil infiltration. Lastly, the filled soil surface was leveled and ridge system was created. Then the small seedlings of $S$. novi-belgii and D. chinensis L. in trays (6-8 weeks) were directly transplanted into the field in July 2013, and both plant seedlings have heights of about $12-15 \mathrm{~cm}$. Experiment for each herbaceous plant received irrigation water at five levels (0.8 (G1), 3.1 (G2), 4.7 (G3), 6.3 (G4) and $7.8 \mathrm{dS} / \mathrm{m}$ (G5) of salinity, with saline water composed by mixing fresh well-water and highly saline shallow-groundwater in different proportions. 80 plants were planted at a spacing of $0.2 \mathrm{~m} \times 0.3 \mathrm{~m}$ in each $3.0 \mathrm{~m} \times 3.0 \mathrm{~m}$ experimental plot. Each treatment in one plot consisted of four raised $(15 \mathrm{~cm})$ beds as replication, and each bed was $0.3 \mathrm{~m}$ wide and $3.0 \mathrm{~m}$ long with $0.8 \mathrm{~m}$ between bed centers (Fig. 2). There are two rows of plants in each bed.

Each irrigation water salinity level had a separate gravity dripirrigation system consisting of a tank $(200 \mathrm{~L})$ and 8 drip tubes with inside diameter of $16 \mathrm{~mm}$ (four tubes per plot per herbaceous plant). The tank was installed at $0.8 \mathrm{~m}$ above the ground to contain irrigation water. Drip tubes with $0.2-\mathrm{m}$ emitter $(1.38 \mathrm{~L} / \mathrm{h}$ at $100 \mathrm{kPa})$ intervals were placed in the center of the beds. The homogeneity for emitters is $>95 \%$ for all treatments and the water flow ranged from $0.39 \mathrm{~L} / \mathrm{h}$ to $0.53 \mathrm{~L} / \mathrm{h}$ under gravity drip-irrigation in our experiment. One vacuum gauge tensiometer was installed $0.2 \mathrm{~m}$ directly underneath one emitter located in the center of the plot for each treatment. The tensiometers were observed twice daily (at 8:00 and 18:00 h), and irrigation was applied when the reading value of tensiometers exceeded the target soil matric potential (SMP) value. Planting pattern, soil treatment and samplings distributions were shown in Fig. 2.

Irrigation water management was the same as described in $\mathrm{Li}$ et al. (2015a,b). Irrigation time was divided into two stages. The first stage was enhanced salt leaching using freshwater. This stage used the same gravity drip irrigation system. The water head was located $0.5 \mathrm{~m}$ above the soil surface and was controlled by a bucket in which a float had been installed. Two drip tubes were placed at $30 \mathrm{~cm}$ distance. Immediately after transplanting seedlings in July 2013 , freshwater was first applied to reduce the levels of soil salinity within the $0-10 \mathrm{~cm}$ soil layer. After that, the transplants were still establishing, so if SMP fell below $-5 \mathrm{kPa}$ then all the treatments were uniformly irrigated to maintain SMP at $-5 \mathrm{kPa}$, until all plants had successfully established in the soil. The second stage was water and salt regulation using saline water. Irrigation started based on SMP. The target SMP value was greater than the corresponding value of SMP for field capacity ( $\sim 8 \mathrm{kPa}$ ) in the early time, to cause a vertical downward soil water potential gradient which benefited salt leaching. Based on the experimental results of Sun et al. (2012, 2013), we set the SMP threshold at $-5 \mathrm{kPa}$ when the plants were transplanted, and $-10 \mathrm{kPa}$ in the second year and $-13 \mathrm{kPa}$ in the third year combining with saving-water and soil salinity environment. Water treatments based on different EC of irrigation water were initiated in August 2013. The treatments were connected to individual gravity drip irrigation systems which irrigated the plants from 200-L tank containing irrigation water. The amount of water for each irrigation event of all treatments was $6 \mathrm{~mm}$ when SMP reached the threshold value, which considered the ability to retain moisture in the soil (soil water reserves) and the maximum daily evapotranspiration of plants in the local area.

On 21-24 November of 2013-2015, $24 \mathrm{~mm}$ of freshwater irrigation was applied to each treatment and then irrigation was terminated until April due to the onset of winter. On 6-8 April of 2014-2015, $24 \mathrm{~mm}$ of freshwater irrigation was applied to each treatment to provide a suitable soil moisture environment for plant sprouting in spring. In other experiment periods, saline water irrigation was applied.

Each irrigation water salinity treatment for both herbaceous plants had the same amount of fertilizer. Phosphoric acid, urea and potassium dihydrogen phosphate were added into the tank and dissolved in water so that the fertilizer was applied with the irrigation water, in annual amounts of 60,73 and $59 \mathrm{~kg} / \mathrm{ha}$, respectively.

\subsection{Observation and measurements}

The number of surviving plants was counted in 2013-2015. The shoot biomass of plants (three plants per treatment) was measured at the end of 2014. Soil cores were obtained from each plot using an auger $(2.0 \mathrm{~cm}$ diameter, $15 \mathrm{~cm}$ high) before transplanting and on November 2014. The samples were obtained at 0, 10, 20, 30 and $40 \mathrm{~cm}$ from the emitters. Soil samplings distribution was shown in Fig. 2.

All soil samples were air-dried and passed through a 1-mm sieve. Soluble salt estimates, soluble cations and soil $\mathrm{pH}$ were based on extracts of saturated soil. The EC and $\mathrm{pH}$ were determined using a conductivity meter (DDS-11A, REX, Shanghai) and a pH meter(PHS3C, REX, Shanghai), respectively (Sun et al., 2012, 2013). The SAR of the saturated paste extract was calculated as follows (Rhoades et al., 1992):

$\mathrm{SAR}=\frac{\left[\mathrm{Na}^{+}\right]}{\left(\left[\mathrm{Ca}^{2+}\right]+\left[\mathrm{Mg}^{2+}\right]\right)^{0.5}}$

where the concentration of each cation is in $\mathrm{mmol} / \mathrm{L}$.

In this experiment, average $\mathrm{EC}_{\mathrm{e}}$ values within the whole soil profile were integrated to account for both spatial and temporal variations. The average values of $\mathrm{EC}_{\mathrm{e}}$ in the soil profile were calculated as follows (Dou et al., 2011):

$\mathrm{EC}_{\mathrm{e}}(t)=\frac{\sum_{j, k}^{n, m} \mathrm{EC}_{\mathrm{e}}(t, j, k) \times \mathrm{S}(j, k)}{\sum_{j, k}^{n, m} \mathrm{~S}(j, k)}$ 
Table 1

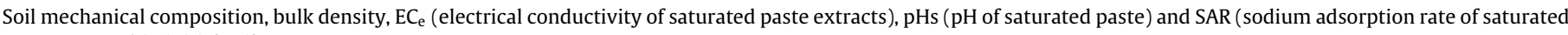
paste extracts) in initial soil.

\begin{tabular}{|c|c|c|c|c|c|c|c|c|}
\hline \multirow[t]{2}{*}{ Soil depth $(\mathrm{cm})$} & \multicolumn{3}{|c|}{ Soil mechanical composition (\%) } & \multirow[t]{2}{*}{ Soil texture } & \multirow[t]{2}{*}{ Bulk density $\left(\mathrm{g} / \mathrm{cm}^{3}\right)$} & \multirow[t]{2}{*}{$\mathrm{EC}_{\mathrm{e}}(\mathrm{dS} / \mathrm{m})$} & \multirow[t]{2}{*}{$\mathrm{pHs}$} & \multirow[t]{2}{*}{$\mathrm{SAR}(\mathrm{mmol} / \mathrm{L})^{0.5}$} \\
\hline & $<0.002 \mathrm{~mm}$ & $0.002-0.05 \mathrm{~mm}$ & $0.05-2 \mathrm{~mm}$ & & & & & \\
\hline $0-5$ & 0.34 & 40.20 & 59.46 & Sandy & 1.29 & 27.55 & 7.93 & 52.34 \\
\hline $5-15$ & 0.49 & 43.68 & 55.83 & loam & 1.32 & 26.98 & 7.91 & 54.56 \\
\hline $15-25$ & 0.54 & 43.45 & 56.01 & & 1.41 & 28.56 & 8.04 & 55.23 \\
\hline $25-35$ & 0.48 & 41.32 & 58.20 & & 1.51 & 26.83 & 8.10 & 55.66 \\
\hline $35-45$ & 0.55 & 41.99 & 57.46 & & 1.62 & 29.23 & 8.02 & 54.89 \\
\hline $45-55$ & 0.60 & 43.55 & 55.85 & & 1.66 & 27.45 & 7.88 & 53.87 \\
\hline $55-75$ & 0.50 & 44.65 & 54.85 & & 1.69 & 26.99 & 7.87 & 49.78 \\
\hline $75-95$ & 0.58 & 46.98 & 52.44 & & 1.71 & 27.56 & 7.88 & 48.99 \\
\hline
\end{tabular}

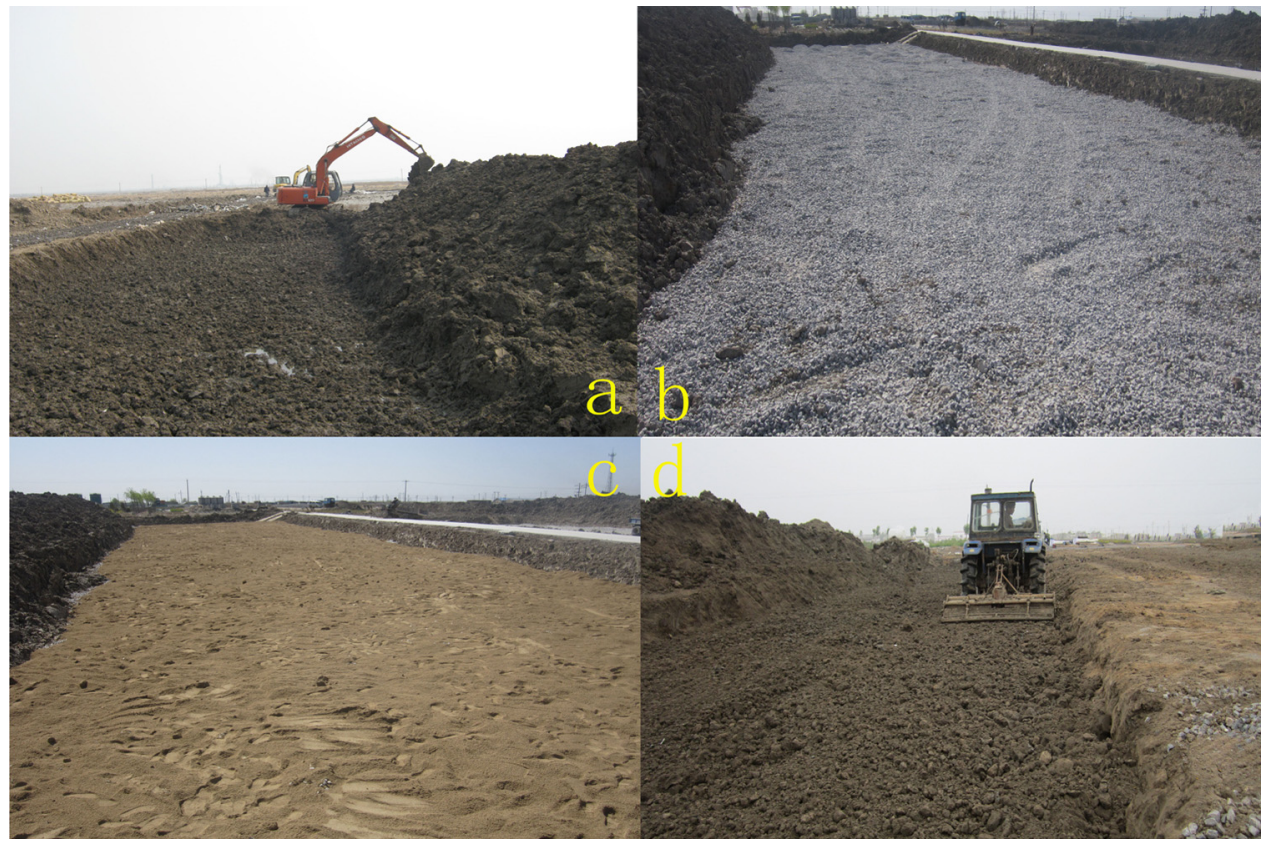

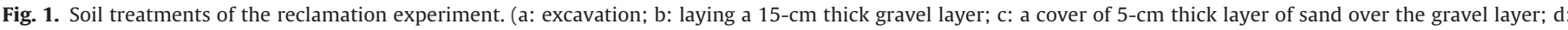
native saline soil backfill and rototillering).

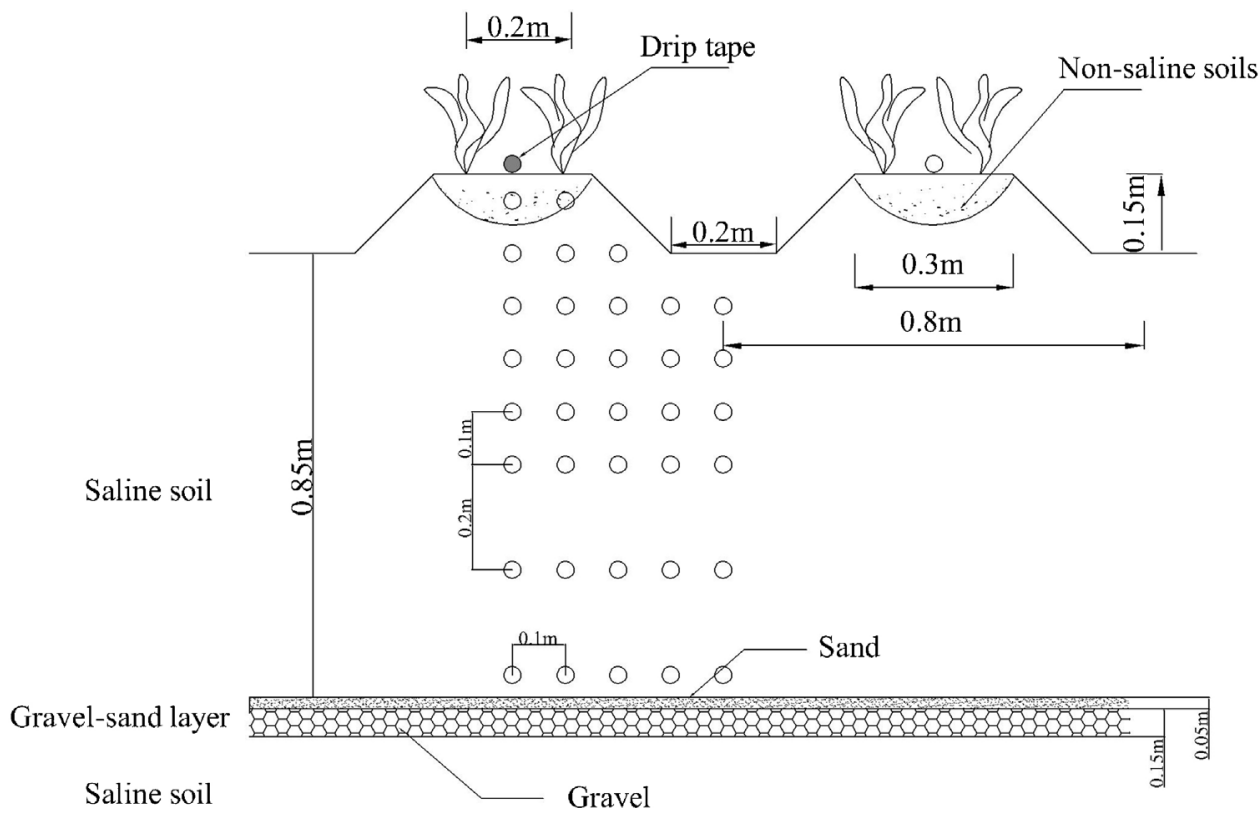

Fig. 2. Planting pattern, soil treatment and soil samplings distribution. 
Table 2

Rainfall and saline water irrigation amount for each treatment during 2013-2015.

\begin{tabular}{|c|c|c|c|c|c|c|c|c|c|c|c|}
\hline \multirow[t]{2}{*}{ Treatments } & \multirow[t]{2}{*}{$\mathrm{EC}_{\mathrm{iw}}(\mathrm{dS} / \mathrm{m})$} & \multicolumn{5}{|c|}{ Rainfall (mm) } & \multicolumn{5}{|c|}{ Saline water irrigation depth (mm) } \\
\hline & & $\begin{array}{l}2013 \\
\text { (Jul-Nov) }\end{array}$ & $\begin{array}{l}2014 \\
\text { (Jul-Nov) }\end{array}$ & $\begin{array}{l}2014 \\
\text { (Apr-Nov) }\end{array}$ & $\begin{array}{l}2015 \\
\text { (Jul-Nov) }\end{array}$ & $\begin{array}{l}2015 \\
\text { (Apr-Nov) }\end{array}$ & $\begin{array}{l}2013 \\
\text { (Jul-Nov) }\end{array}$ & $\begin{array}{l}2014 \\
\text { (Jul-Nov) }\end{array}$ & $\begin{array}{l}2014 \\
\text { (Apr-Nov) }\end{array}$ & $\begin{array}{l}2015 \\
\text { (Jul-Nov) }\end{array}$ & $\begin{array}{l}2015 \\
\text { (Apr-Nov) }\end{array}$ \\
\hline G1 & 0.8 & 409.9 & 328.7 & 415.6 & 394.9 & 565.2 & 210 & 114 & 342 & 72 & 168 \\
\hline G2 & 3.1 & & & & & & 264 & 138 & 318 & 84 & 204 \\
\hline G3 & 4.7 & & & & & & 246 & 72 & 240 & 66 & 132 \\
\hline G4 & 6.3 & & & & & & 372 & 120 & 318 & 108 & 216 \\
\hline G5 & 7.8 & & & & & & 348 & 186 & 384 & 54 & 186 \\
\hline Average & & & & & & & 288.0 & 126.0 & 320.4 & 76.8 & 181.2 \\
\hline
\end{tabular}

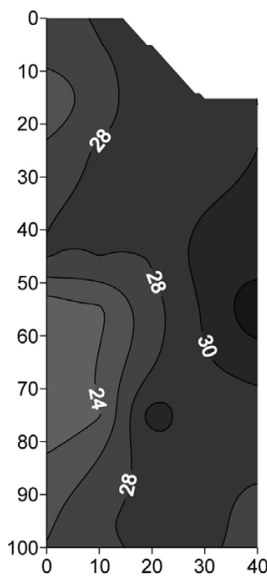

G0

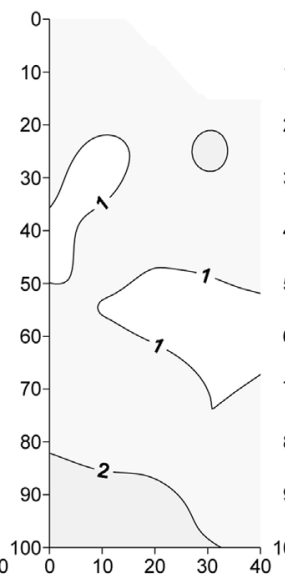

$0.8 \mathrm{dS} / \mathrm{m}$

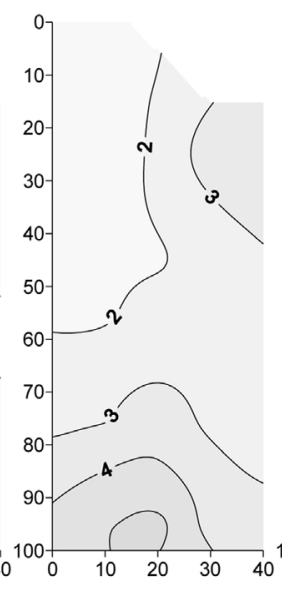

$3.1 \mathrm{dS} / \mathrm{m}$

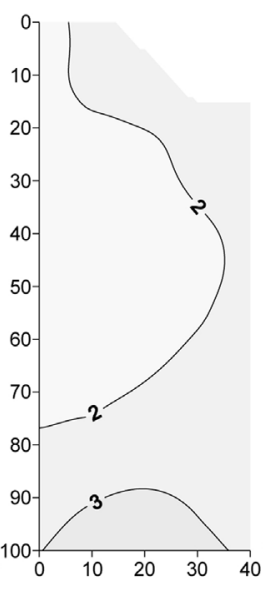

$4.7 \mathrm{dS} / \mathrm{m}$
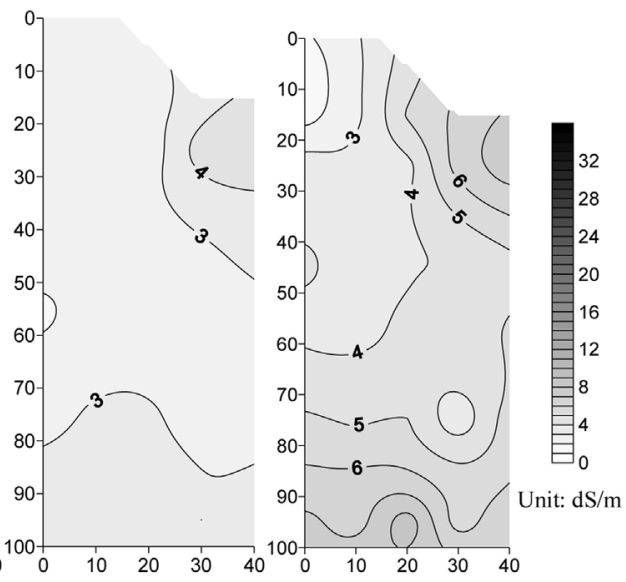

$6.3 \mathrm{dS} / \mathrm{m}$

\section{$7.8 \mathrm{dS} / \mathrm{m}$}

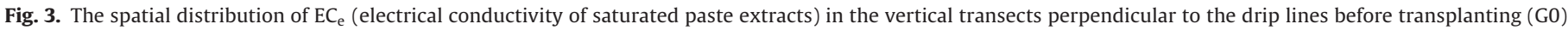
and for each treatment in 2014. 11 (G1-G5).

where $t$ represents the time at which soil samples were obtained; $j$ the distances from the emitter where soil samples were attained; $k$ the depths of soil samples and $\mathrm{S}(j, k)$ the depth interval of the soil sample.

\subsection{Statistical analyses}

One empirical function was compared to describe the survival rate and shoot dry matter production of S. novi-belgii and $D$. chinensis L. while subject to increasing salinity levels of irrigation water. Model is as follows:

$\mathrm{PIr}=100-\mathrm{PId}\left(\mathrm{EC}_{\mathrm{iw}}-\mathrm{EC}_{\mathrm{t}}\right)$

where PIr is the relative plant index (actual plant index at the given salinity level divided by plant index with fresh water or low saline water), $\mathrm{EC}_{\mathrm{iw}}$ represents the irrigation water salinity (EC of the irrigation water, $\mathrm{dS} / \mathrm{m}$ ), $\mathrm{EC}_{\mathrm{t}}$ is the threshold salinity level (the maximum allowable salinity that does not reduce plant index measurably below that of a non-saline condition or irrigated with fresh water or low saline water, $\mathrm{dS} / \mathrm{m}$ ), and PId is the plant index decrease per unit of salinity increase beyond the threshold.

All data gathered in the research were recorded and classified in Microsoft Office Excel 2007. Analyses of variance (ANOVA) were carried out by SPSS 16.0 statistical software (SPSS Inc., IL, USA). The significance of the effect of all variables was examined by one-way ANOVA. Figures were created using Surfer 8.0 (Golden Software Inc., CO, USA) and Origin 8.0 (Origin Lab Inc., MA, USA).

\section{Results and discussion}

\subsection{Rainfall and irrigation}

During the experiment period, the total rainfall was 409.9, 415.5 and $565.2 \mathrm{~mm}$ in 2013-2015, respectively (Table. 2), but the precipitation in the period of July-November was similar in the three years. The amounts of irrigation with saline water were $210-372 \mathrm{~mm}, 240-384 \mathrm{~mm}$ and $132-204 \mathrm{~mm}$ in 2013-2015, respectively. For the same period (Jul-Nov), less irrigation water were applied for all treatments with the values of $72-186 \mathrm{~mm}$ and 54-108 in 2014 and 2015, respectively. The irrigation amounts decreased with year in the same period (Jul-Nov), and this was mainly because that the SMP threshold value was controlled lower with year.

\subsection{Salt leaching}

On the experimental land before transplanting ofplants, the average $\mathrm{EC}_{\mathrm{e}}$ value in the $0-95 \mathrm{~cm}$ soil profile was up to $27.64 \mathrm{dS} / \mathrm{m}$ (Table 1 and Fig. 3 G0). After nearly 18 months of drip-irrigation with saline water, the salts in all of the sampled layers were well leached. The average $\mathrm{EC}_{\mathrm{e}}$ value in soil profile for five treatments was 2.32 and $2.78 \mathrm{dS} / \mathrm{m}$ in $0-35$ and $0-95 \mathrm{~cm}$, respectively, which were reduced by $91.6 \%$ and $89.9 \%$ compared to the corresponding initial $\mathrm{EC}_{\mathrm{e}}$ values prior to planting. The salinity in the $0-35$ and $0-95 \mathrm{~cm}$ soil profile decreased from 'very severe' $\left(\mathrm{EC}_{\mathrm{e}}>16 \mathrm{dS} / \mathrm{m}\right)$ to 'mild' ( $\left.2 \mathrm{dS} / \mathrm{m}<\mathrm{EC}_{\mathrm{e}}<4 \mathrm{dS} / \mathrm{m}\right)$, and many salt-sensitive plants could naturally grow at this soil condition. Salt leaching occurred for all soil profiles, but the effect decreased with soil depth and the distance from emitter.After nearly 18 months, The average $\mathrm{EC}_{\mathrm{e}}$ values in $0-35 \mathrm{~cm}$ soil profile were $1.36,1.97,1.91,2.87$ and $3.66 \mathrm{dS} / \mathrm{m}$ 
Table 3

Two herbaceous plants growth characteristics for different irrigation water quality $\left(\mathrm{EC}_{\mathrm{iw}}\right)$ in two years.

\begin{tabular}{|c|c|c|c|c|c|c|}
\hline \multirow[t]{3}{*}{ Treatments } & \multicolumn{4}{|c|}{ Survival rate (\%) } & \multicolumn{2}{|l|}{ Shoot dry mass (g) } \\
\hline & \multicolumn{2}{|c|}{ Symphyotrichum novi-belgii } & \multicolumn{2}{|c|}{ Dianthus chinensis L. } & \multicolumn{2}{|l|}{2014.11} \\
\hline & 2014.8 & 2015.8 & 2014.8 & 2015.8 & Symphyotrichum novi-belgii & Dianthus chinensis L \\
\hline $\mathrm{G} 1(0.8 \mathrm{dS} / \mathrm{m})$ & $98.61 \mathrm{a}$ & $97.22 \mathrm{a}$ & $98.75 a$ & $97.50 \mathrm{a}$ & $83.33 a$ & $72.83 a$ \\
\hline $\mathrm{G} 2(3.1 \mathrm{dS} / \mathrm{m})$ & $98.61 \mathrm{a}$ & $97.22 \mathrm{a}$ & $98.75 a$ & $97.50 \mathrm{a}$ & $74.67 \mathrm{~b}$ & $68.83 b$ \\
\hline $\mathrm{G} 3(4.7 \mathrm{dS} / \mathrm{m})$ & $98.61 \mathrm{a}$ & $95.83 a$ & $98.75 a$ & $95.00 \mathrm{~b}$ & $59.33 c$ & $42.97 c$ \\
\hline $\mathrm{G} 4(6.3 \mathrm{dS} / \mathrm{m})$ & $97.22 \mathrm{a}$ & $95.83 a$ & $97.50 a$ & $90.00 \mathrm{c}$ & $39.07 d$ & $40.67 c$ \\
\hline $\mathrm{G} 5(7.8 \mathrm{dS} / \mathrm{m})$ & $94.44 a$ & $94.44 a$ & $90.00 \mathrm{~b}$ & $80.00 d$ & $34.17 \mathrm{c}$ & $35.20 \mathrm{~d}$ \\
\hline
\end{tabular}

Values followed by different letters within the same year in column differ significantly at $p<0.05$.

for G1-G5, respectively, and the corresponding values in $0-95 \mathrm{~cm}$ soil profile were $1.48,2.69,2.18,2.88$ and $4.70 \mathrm{dS} / \mathrm{m}$, respectively, which were reduced by $86.7 \%-95.0 \%$ in $0-35 \mathrm{~cm}$ and $83.0 \%-94.6 \%$ in $0-95 \mathrm{~cm}$ compared to the corresponding initial $\mathrm{EC}_{\mathrm{e}}$ values prior to planting. In the present study, good salt leaching effect occurred under drip-irrigation, with saline soil becoming mildly saline or even non-saline as planting age increases (Kang et al., 2012; Li et al., 2015a,b). In addition, salt leaching effects decreased with irrigation water salinity increasing.

\subsection{Survival rate and shoot dry mass}

The data of plant survival rate and shoot dry mass of twoplants for different treatments during the experiment and the ANOVA results are shown in Table 3. Many studies reported that plant growth and dry weight could be significantly affected by salinity, which has been confirmed in crops and other plants (Chauhan et al., 2008; Karlberg et al., 2007; Mantell et al., 1985; Oster and Schroer 1979; Rhoades, 1977). In the present study, the survival rates of $S$. novi-belgii were $>90 \%$ at $\mathrm{EC}_{\mathrm{iw}}<7.8 \mathrm{dS} / \mathrm{m}$ in 2014 and 2015 , respectively. The corresponding values of $D$. chinensis $L$. were $>90 \%$ at $\mathrm{EC}_{\mathrm{iw}}<6.3 \mathrm{dS} / \mathrm{m}$.

At the end of 2014, some plants shoots were collected to determine the shoot dry mass (Table 3 ). Irrigation with saline water had a negative effect on shoot dry mass. The shoot dry masses for $S$. novi-belgii and D. chinensis $\mathrm{L}$. at $\mathrm{EC}_{\mathrm{iw}}$ of $0.8 \mathrm{dS} / \mathrm{m}$ were 83.33 and $72.83 \mathrm{~g} /$ plant, respectively, which were higher 49.16 and $37.63 \mathrm{~g} /$ plant than those at $\mathrm{EC}_{\mathrm{iw}}$ of $7.8 \mathrm{dS} / \mathrm{m}$. Shoot dry weights significantly decreased with irrigation water salinity increasing, likely due to decreased plant growth and changes in physiology caused by irrigation with saline water. It has been reported that water uptake (Mantell et al., 1985; Rogers, 2001; Romero-Aranda et al., 2001), stomatal density (Prior et al., 1992), transpiration (Romero-Aranda et al., 2001; Valdez-Aguilar et al., 2011), net $\mathrm{CO}_{2}$ assimilation and leaf photosynthesis (Prior et al., 1992) are reduced as irrigation water salinity increases. Dry matter production also declined due to decreased light interception from the reduction in leaf area (Alarcon et al., 1994; Kutuk et al., 2004).

\subsection{Salt tolerance threshold}

We used one model to evaluate the effect of saline water irrigation on survival rate and shoot dry weight (Fig. 4). The salt tolerance threshold (STI) value of S. novi-belgii was $3.68 \mathrm{dS} / \mathrm{m}$ according to analysis of the linear relationship between $\mathrm{EC}_{\mathrm{iw}}$ and survival rate; and the survival rate decreased by $0.76 \%$ for each unit of EC increase in irrigation water. The corresponding values were $3.99 \mathrm{dS} / \mathrm{m}$ and $3.01 \%$ for $D$. chinensis L. Although the STI value of S. novi-belgii is slightly lower than that of Pinks, the reduction in survival rate for each unit of $\mathrm{EC}_{\mathrm{iw}}$ is lower than that of $D$. chinensis $\mathrm{L}$.

Analysis of the linear relationship between shoot dry weight and $\mathrm{EC}_{\mathrm{iw}}$ showed that the STI value of S. novi-belgii was $1.27 \mathrm{dS} / \mathrm{m}$, and shoot dry weight decreased by $9.24 \%$ for each unit of EC increase (a) Symphyotrichum novi-belgii

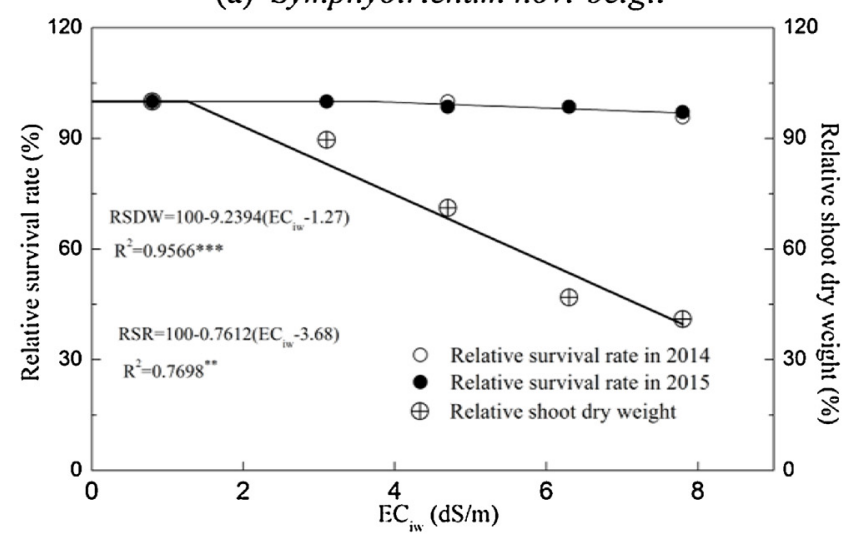

(b) Dianthus chinensis L.

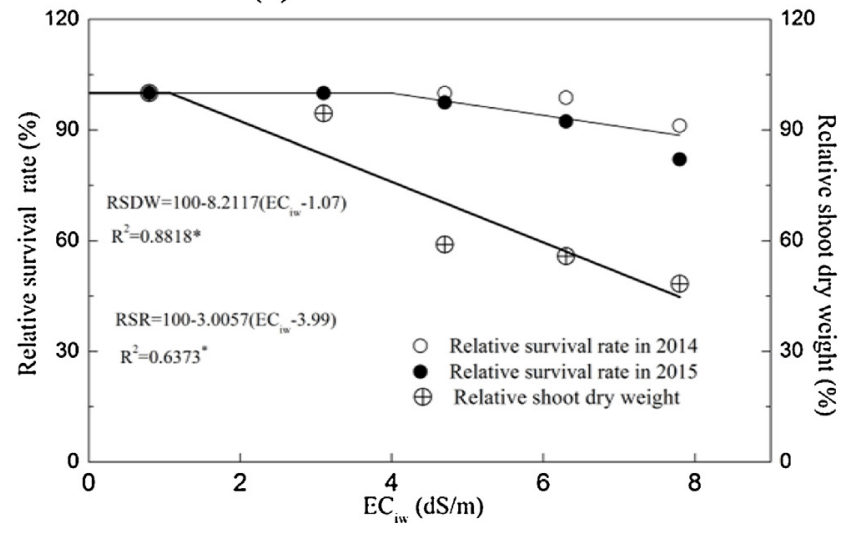

Fig. 4. The response of relative survival rate (RSR) and relative shoot dry weight (RSDW) of 2014 to $\mathrm{EC}_{\mathrm{iw}} \cdot{ }^{* *} p<0.05$.

in irrigation water. The corresponding values were $1.07 \mathrm{dS} / \mathrm{m}$ and 8.21\% for Pinks. This study indicated that although higher survival rates observed in the two plants, shoot dry mass is sensitive to salinity, which also has been confirmed in Chinese rose (Rosa chinensis) and stonecrop (Sedum spectabile Boreau) (Li et al., 2015a,b,d).

\section{Conclusions}

The present study showed that drip-irrigation worked well in combination with saline water for the survival of $S$. novi-belgii and D. chinensis L. in a coastal saline soil. Soil salts were well leached and the very heavy saline soils became mildly or even non-saline soils after 18 months of reclamation. Irrigation water salinity significant decreased shoot dry mass of $S$. novi-belgii and $D$. chinensis L., but slightly affected survival rate, especially for S. novi-belgii. The survival rates were $>90 \%$ when irrigated with saline water at $<7.8$ and 
$6.3 \mathrm{dS} / \mathrm{m}$ for S. novi-belgii and $D$. chinensis L., respectively. This study implied that $S$. novi-belgii and $D$. chinensis $L$. are suitable plants in landscape cultivated in coastal saline soil by drip-irrigation with saline water at $\mathrm{EC}_{\mathrm{iw}}<7.8 \mathrm{dS} / \mathrm{m}$ with survival rate $>80 \%$, and an SMP above $-5 \mathrm{kPa}$ at $20 \mathrm{~cm}$ depth under the emitter after transplanted and $-10 \mathrm{kPa}$ and $-13 \mathrm{kPa}$ after growing season ended, and $6 \mathrm{~mm}$ of irrigation water can be used as indicators for S. novi-belgii and $D$. chinensis L. drip-irrigation scheduling.

\section{Acknowledgements}

This study was supported by the National High Technology R\&D Program of China (Grant No. 2013BAC02B02 and 2013BAC02B01), the Action Plan for the Development of Western China of the Chinese Academy of Sciences (Grant No. KZCX2-XB3-16), and the National Science Foundation for Young Scientists of China (Grant No. 51509238 and 51409126).

\section{References}

Alarcon, J., Bolarin, M., Sanchezblanco, M., Torrecillas, A., 1994. Growth, yield and water relations of normal fruited and cherry tomato cultivars irrigation with saline water. J. Hortic. Sci. Biotech. 69, 283-288.

Chauhan, C.P.S., Singh, R.B., Gupta, S.K., 2008. Supplemental irrigation of wheat with saline water. Agric. Water Manage. 95, 253-258.

Chen, X.Y., Kang, Y.H., Wan, S.Q., Chu, L.L., Li, X.B., 2015. Chinses rose (Rosa chinensis) cultivation in Bohai Bay, China, using an improved drip irrigation method to reclaim heavy coastal saline soils. Agric. Water Manage. 158, 99-111.

Dou, C.Y., Kang, Y.H., Wan, S.Q., Hu, W., 2011. Soil salinity changes under cropping with Lycium barbarum L. and irrigation with saline-Sodic water. Pedosphere 21, 539-548.

Kang, Y., Wang, R., Wan, S., Hu, W., Jiang, S., Liu, S., 2012. Effects of different water levels on cotton growth and water use through drip irrigation in an arid region with saline ground water of Northwest China. Agric. Water Manage. 109, $117-126$.

Karlberg, L., Rockstrom, J., Annandale, J.G., Steyn, J.M., 2007. Low-cost drip irrigation-A suitable technology for southern Africa? An example with tomatoes using saline irrigation water. Agric. Water Manage. 89, 59-70.
Kutuk, C., Cayci, G., Heng, L.K., 2004. Effects of increasing salinity and N-15-labelled urea levels on growth, $\mathrm{N}$ uptake, and water use efficiency of young tomato plants. Aust. J. Soil Res. 42, 345-351.

Li, X., Kang, Y., Wan, S., Chen, X., Chu, L., 2015a. Reclamation of very heavy coasta saline soil using drip-irrigation with saline water on salt sensitive plants. Soil Tillage Res. 146, 159-173.

Li, X., Kang, Y., Wan, S., Chen, X., Xu, J., 2015b. Effect of drip-irrigation with saline water on Chinese rose (Rosa chinensis) during reclamation of very heavy coastal saline soil in a field trial. Sci. Hortic. 186, 163-171.

Li, X., Kang, Y., Wan, S., Chen, X., Chu, L., Xu, J., 2015c. First and second-year assessments of the rapid reconstruction and re-vegetation method for reclaiming two saline-sodic, coastal soils with drip-irrigation. Ecol. Eng. 84 , 496-505.

Li, X., Kang, Y., Wan, S., Chen, X., Liu, S., Xu, J., 2015d. A vegetation reconstruction method to plant Sedum spectabile Boreau using drip-irrigation with saline water on a coastal saline soil in region around Bohai Gulf. Paady Water Environ., http://dx.doi.org/10.1007/s10333-015-0518-7.

Mantell, A., Frenkel, H., Meiri, A., 1985. Drip irrigation of cotton with saline-sodic water. Irrig. Sci. 6, 95-106.

Oster, J.D., Schroer, F.W., 1979. Infiltration as influenced by irrigation water-quality. Soil Sci. Soc. Am. J. 43, 444-447.

Prior, L., Grieve, A., Cullis, B., 1992. Sodium-chloride and soil texture interactions in irrigation field-grown sultana grapevines. 2. Plant mineral-content, growth and physiology. Aust. J. Agric. Res. 43, 1067-1083.

Rhoades JD, Kandiah A, Mashali AM, 1992. The use of saline waters for crop production food and agriculture organization of the United Nations., pp. 1-132.

Rhoades, J., 1977. Potential for using saline agricultural drainage water for irrigation. Water Manage. Irrig. Drain, 85-116.

Rogers, M., 2001. The effect of saline irrigation on lucerne production: shoot and root growth ion relations and flowering incidence in six cultivars grown in northern Victoria. Aust. Irrig. Sci. 20, 55-64.

Romero-Aranda, R., Soria, T., Cuartero, J., 2001. Tomato plant-water uptake and plant-water relationships under saline growth conditions. Plant Sci. 160, 265-272.

Sun, J.X., Kang, Y.H., Wan, S.Q., Hu, W., Jiang, S.F., Zhang, T.B., 2012. Soil salinity management with drip irrigation and its effects on soil hydraulic properties in north China coastal saline soils. Agric. Water Manage. 115, 10-19.

Sun, J.X., Kang, Y.H., Wan, S.Q., 2013. Effects of an imbedded gravel-sand layer on reclamation of coastal saline soils under drip irrigation and on plant growth. Agric. Water Manage. 123, 12-19.

Valdez-Aguilar, L.A., Grieve, C.M., Razak-Mahar, A., McGiffen, M.E., Merhaut, D.J., 2011. Growth and ion distribution is affected by irrigation with Saline water in selected landscape species grown in two consecutive growing seasons: spring-summer and fall-winter. Hortscience 46, 632-642. 